\title{
Alteration of Dentate Gyrus Astrocytes in Diabetic Rats: Protective Role of Urtica dioica
}

\author{
Alteración de los Astrocitos del Giro Dentado en Ratas Diabéticas: \\ Rol Protector de Urtica dioica
}

"Mohammad Jafar Golalipour; "*Soraya Ghafari; **Mohammad Hossein Latifimoghadam \& *** Sakineh Kaboli

GOLALIPOUR, M. J.; GHAFARI, S.; LATIFIMOGHADAM, M. H. \& KABOLI, S. Alteration of dentate gyrus astrocytes in diabetic rats: Protective role of Urtica dioica. Int. J. Morphol., 29(4):1307-1312, 2011.

SUMMARY: Diabetes mellitus can cause astrocytes alterations in the central nervous system. Urtica dioica (Nettle) is among several species listed for their use against diabetes in folk medicine. Therefore, this study was done to evaluate the protective effect of Urtica dioica on astrocytes density of the dentate gyrus in STZ induced diabetic rats. In this experimental study, 21 male albino Wistar rats were randomly allocated equally into normal, diabetic and protective (nettle treated diabetic) groups. Hyperglycemia was induced by streptozotocin $(80 \mathrm{mg} / \mathrm{kg})$ in the animals of diabetic and treatment groups. Before induction of diabetes in animals, animals in protective group received hydroalcoholic extract of Urtica dioica $(100 \mathrm{mg} / \mathrm{kg} / \mathrm{BW} /$ day $)$ for five days intraperitoneally. Four weeks after induction of diabetes, animals were sacrificed and coronal sections were taken from the dorsal hippocampal formation of the right cerebral hemispheres and stained with PTAH stain. The area densities of the astrocytes were measured and compared in the three groups ( $<<0.05)$. The number of astrocytes in DG area of controls was 17.72 \pm 6.7 . The density of astrocytes increased in diabetic (24.26 \pm 9.5$)$ in comparison with controls. The density in the nettle treated rats $(23.17 \pm 5.8)$ was lower than diabetic rats. This study showed that the administration of $U$. dioica extract before induction of diabetes can not significantly help compensate for astrocytes in the dentate gyrus of treated rats.

KEY WORDS: Diabetes; Astrocyte; Urtica dioica; Dentate gyrus.

\section{INTRODUCTION}

Diabetes mellitus is the most common serious metabolic disorders (Gispen \& Biessels, 2000). A variety of functional and morphological alterations in the central nervous system can be caused by Diabetes mellitus (Biessels et al., 1994). These changes include abnormal expression of hypothalamic neuropeptides, astrogliosis in the hippocampus (Saravia et al., 2002), decreased synaptic plasticity in the hippocampus, neurotoxicity, and changes in glutamate neurotransmission (Revsin et al., 2005).

Several evidences have shown that diabetes may be associated with learning and memory deficits in humans (Biessels et al., 1994; Brands et al., 2005; Liang et al., 2006).

Studies examining the effects of streptozotocin-induced diabetes on memory function in mice and rat models have also shown deficits in memory retention and retrieval, compared to non-diabetic controls (Biessels \& Gispen, 2005;
Biessels et al., 1996; Gispen \& Biessels; Trudeau et al., 2004).

Astrocytes have effective roles in supporting of neurons, scar formation and maintenance of the blood-brain barrier (Afsari et al., 2008), vascular reactivity, regulation of extracellular glutamate levels, energy metabolism, and protection from reactive oxygen species in the central nervous system (Dringen et al., 2000; Tsacopoulos \& Magistretti, 1996; Zonta et al., 2003).

These evidences indicate that altered astrocyte activity contributes to the CNS pathophysiology in diabetes mellitus.

Some researches have indicated that diabetes led to astroglial alterations as increasing of number of astrocytes (Saravia et al.; Baydas et al., 2003a; Revsin et al.; Baydas et al., 2003b).

\footnotetext{
Professor, Gorgan congenital malformations research center, Department of Anatomical sciences, Golestan University of medical Sciences, Gorgan, Iran.

** Department of Anatomical sciences, Golestan University of medical Sciences, Gorgan, Iran.

**** Development Department, Islamic Azad University, Damghan Branch, Damghan, Iran.
} 
In recent years, there has been renewed interest in plant medicine for the treatment against different diseases (Kameswara Rao et al., 2003; Ladeji et al., 2003).

Isolated studies screened various plants having "folk medicine reputation" by biochemical test for this antidiabetogenic effect (Vats et al., 2002).

Urtica dioica L. Stinging nettle (Urticacea) is annual and perennial herb, distinguished with stinging hairs (Kavalali et al., 2003). Among the Urtica species, Urtica dioica (U. dioica) has been known for a long time as medicinal plants in the world. The blood sugar lowering effect of $U$. dioica as a medicinal herb has been introduced in old script such as those written by Avicenna (Farzami et al., 2003). In addition, U. dioica is among several species listed for their use against diabetes in folk medicine in a large pharmacological screen of European species (Atta-UrRahman \& Zaman, 1989).

Since the dentate gyrus is an important site for adult neurogenesis in mammals and neuropathological damage occurs in diabetic cases also, there is almost no documentation regarding the effects of protective with nettle before induction of diabetes on astrocytes density of dentate gyrus in diabetic rats, therefore, this study was carried out on animal model to evaluate the protective effect of Urtica dioica on astrocytes density of the dentate gyrus (DG) in STZ induced diabetic rats.

\section{MATERIAL AND METHOD}

In this Experimental study 21 adult male Wistar rats (weighing 250-300 g) were used. All animals were treated in agreement with the Helsinki Convention on the use of animals in research approved by the Institutional Review Board. The animals were kept in air-conditional animal room $\left(22 \pm 2^{\circ} \mathrm{C}\right)$ under a $12 \mathrm{~h}$ light/dark cycle.

Collection of Plant. Fresh leaves of $U$. dioica were collected from cultivated plant, from suburb of Gorgan, northern Iran (Golestan, Iran) in October 2005 and taxonomically identified by Department of Pharmacognosy, Mazandaran University of Medical Sciences. A voucher specimen (5-77-1) was deposited in the herbarium of Mazandaran University.

Preparation of extract of Urtica dioica. The dried and powered of $U$. dioica leaves (400 gram) were percolated by Ethanol (45\%) solvent. In briefly the dried leaf of $U$. dioica (by using hot air $35-40^{\circ} \mathrm{C}$ ) powdered by mechanical milling. Prelinering maceration during 5 hours was done and the product percolated and mixing during 48 hours. The extract was filtrated (0.8 Micron) and spray dried in a lab plant SD4 spray drier (lab plant ltd, England).

Chemical. All chemical such as Streptozotocin (STZ) used were of analytical grade obtained from Merck and Sigma.

Experiment induction of diabetes. Streptozotocin was dissolved in saline immediately use and intraperitoneally injected. Diabetes was induced with a single IP injection of Streptozotocin (STZ) $(80 \mathrm{mg} / \mathrm{kg})$ to overnight fast rats. Blood samples for glucose measurements were taken from the tail vein. Diabetes was confirmed by measuring the glucose concentration by using Glucometer method. In the experiments, seven rats were used in each group.

Study design. For this study three groups designed: Normal healthy control group (Group I), received saline daily for 5 days. Diabetic group (Group II) received saline daily for 5 days before STZ injection and protective Group (Group III), diabetic rats received $100 \mathrm{mg} / \mathrm{kg} / \mathrm{BW} /$ daily hydroalcoholic extract of $U$. dioica (Gülçin et al., 2004; Kavalali et al.) for 5 days before STZ injection.

Glucose tolerance test (GTT). GTT was performed on $16 \mathrm{~h}$ fasted rats using $2 \mathrm{~g}$ glucose $/ \mathrm{kg}$ body weight. In all groups, blood was collected from the animals by tail snipping at 0, 30, 90 and 120 minutes after glucose load. Also glucose test were performed after IP injection STZ in 1 and 5 weeks.

Histological and Morphometric studies. After the animals had been scarified, the brains were removed and fixed in buffered formaldehyde $10 \%$ solution for histological analysis. Brains were cut coronally into $7 \mu \mathrm{m}$ slices. Approximately 10 slices obtained from each brain. Then they were processed and were stained with PTAH staining.

Then a photograph of each section was produced using an Olympus BX 51 microscope and a DP 12 digital camera under a magnification of 400'. An area of 20000 $\mu \mathrm{m}^{2}$ was selected in the dentate gyrus in all sections. To measure the area density of the astrocytes, the images were transferred to the computer. Using OLYSIA Autobioreport software, Olympus Co, the appropriate grids were superimposed on the pictures and the cells were counted manually.

Statistical analysis. Data were evaluated using SPSS V.11.5 and one way ANOVA. $\mathrm{P}<0.05$ was considered significant. 


\section{RESULTS}

The fasting blood glucose and Glucose Tolerance Test (GTT) of the three groups at the beginning and the 5th week of the study are shown in Table I and Fig. 1. The GTT results of all rats were normal at the beginning of experiment. At the end of study the control rats which had not received STZ showed a normal GTT. In contrast, the diabetic rats which had undergone STZ-induced diabetes at the first day of study and had not received the nettle extract showed the most profound impairment GTT.
The mean of Astrocytes number (per $20000 \mu \mathrm{m}$ ) in dentate gyrus in control, Diabetic and protective group is depicted on Fig. 2.

Morphometric evaluation in Dentate gyrus showed that, the number of astrocytes in Diabetic group (24.26 \pm 9.5 ) increased in comparison with controls (17.72 \pm 6.7$)$. This difference was significant $(\mathrm{P}<0.05)$.

The density in the nettle treated rats $(23.17 \pm 5.8))$ was lower than diabetic rats $(\mathrm{P}>0.05)$ and higher than controls $(\mathrm{P}<0.05)$.

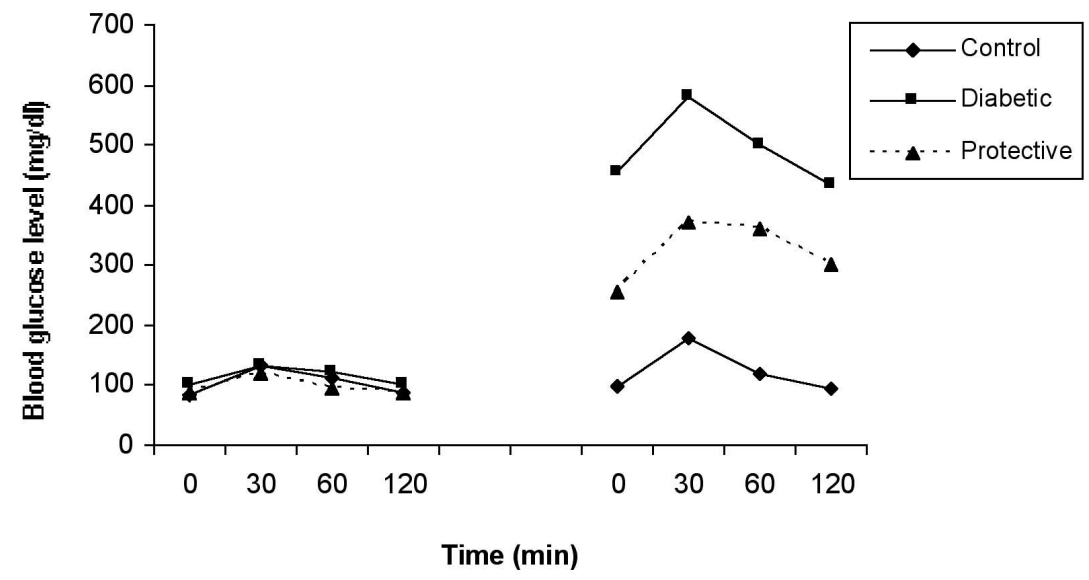

Fig. 1. The glucose tolerance test (GTT) of the three groups at the beginning and the $5^{\text {th }}$ week of the study.

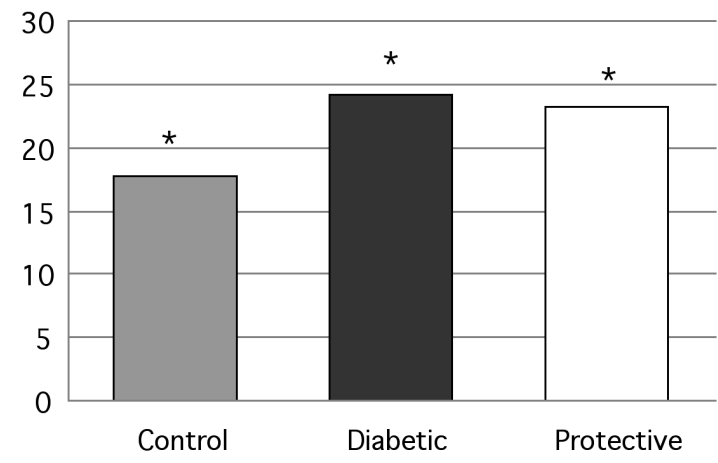

Fig. 2. Mean of astrocytes number in DG in control, diabetic and protective $(U$. dioica) groups $(* \mathrm{P}<0.05)$.

Table I. The fast blood glucose level of the three groups at the beginning and the $1^{\text {th }}, 3^{\text {th }}$ and $5^{\text {th }}$ week of the study.

\begin{tabular}{lcccc}
\hline \multirow{2}{*}{ Group } & \multicolumn{4}{c}{ Blood glucose $\left(\mathbf{m g ~ d L} \mathbf{d L}^{-\mathbf{1}}\right.$} \\
\cline { 2 - 5 } & Initial & $\mathbf{1}$ week & $\mathbf{3}$ week & $\mathbf{5}$ week \\
\hline Control & $84.50 \pm 3.14$ & $86.67 \pm 5.5$ & $88.1 \pm 5$ & $88.5 \pm 8$ \\
Diabetic & $106.83 \pm 11.6$ & $228.3 \pm 72.8$ & $265 \pm 103$ & $476.83 \pm 38.7$ \\
Protective & $88.66 \pm 5$ & $273 \pm 131.9$ & $257.50 \pm 179.8$ & $254.17 \pm 101$
\end{tabular}




\section{DISCUSSION}

This study was designed to evaluate the protective effect of Urtica dioica on astrocytes density of dentate gyrus in STZ induced diabetic rats. According to our findings, the astrocytes number in dentate gyrus of diabetic rats significantly increased in comparison with non diabetic control animals also, the number of astrocytes in protective $U$. dioica treated diabetic animals were non significantly reduced in comparison with diabetic animals.

Our result is similar to previous studies (Saravia et al.; Baydas et al., 2003a; Revsin et al.; Baydas et al., 2003b). Revsin et al. study showed that one month after STZ treatment, the number of astrocytes significantly increased in the STZtreated group as compared to the vehicle treated group.

Saravia et al. showed that the number of GFAP astrocytes increased 3-fold in the hippocampal stratum radiatum of STZ-diabetic female mice compared with age-matched, vehicle-treated non-diabetic controls. The number of GFAPpositive astrocytes increased significantly in the hippocampal formation of diabetic rats. Also, the diameters of astrocytes body were found to be enlarged, and the number and length of foot processes were increased (Muranyi et al., 2006).

The alterations of astrocytes number are possibly due to oxidative stress (Baydas et al., 2003b) and free radical formation (Baydas et al., 2003a). Also Baydas study showed that the gliosis that occurs in diabetes mellitus is mediated, at least indirectly, by free radical formation and antioxidants (Baydas et al., 2003a).

Several mechanisms may account for the astrocyte reaction in streptozotocin-induced diabetes. These mechanisms include increases in the polyol pathway, protein glycation, disturbed calcium homeostasis and oxidative stress (Gispen \& Biessels).

Baydas study showed that the increase of GFAP content and its degradation products and also elevation of S-100B levels are responses of astrocytes to oxidative stress. A significant positive correlation between glial markers and lipid peroxidation in the brain homogenates supports this finding (Baydas et al., 2003a).

Furthermore, previous study (Morgan et al., 1997) reported that increase of GFAP expression during aging is related to oxidative stress. Accumulation of reactive oxygen species promotes astrocyte reactivity and may stimulate the production of trophic factors, thus protecting neurons and/or favouring neuronal recovery.
Several studies showed that astrocytes of hippocampus of diabetic rats can change due to melatonin and vitamin $\mathrm{E}$ (Baydas et al., 2003a; Baydas et al., 2003b).

Vitamin E as an antioxidant agent (Baydas et al., 2003a) and melatonin as a direct scavenger and indirect antioxidant can affect on astrocyte in diabetics model.

In our study, $U$. dioica leaves extract administration before induction of diabetes in animals non significantly reduced astrocytes density of dentate gyrus in diabetic rats.

Furthermore, in our previous studies, $U$. dioica extract administration after induction of diabetes in animals could help to restore diabetes-induced granule cell and astrocytes loss in the rat dentate gyrus (Fazeli et al., 2008; Jahanshahi et al., 2009).

Although, neural cell death protective properties of the extract in the CA1 and CA3 of diabetic mice hippocampus have been attributed to antioxidant and anti-apoptotic properties of $U$. dioica (Fazeli et al., 2010), but low effect of $U$. dioica in recent study may be due to low dosage and short duration of this plant before induction of diabetes and in animals because of in our previous study (Jahanshahi et al.) showed a beneficial treatment for the regulation of cell density in the in DG of diabetes. Of course in our previous study we used $U$. dioica extract for $28 \mathrm{~m}$ days after induction of diabetes.

In conclusion, this study showed that the astrocytes density increase in the diabetic rats and administration of $U$. dioica extract before induction of diabetes for five days can not significantly help compensate for astrocytes in the treated rats hippocampus.

\section{ACKNOWLEDGEMENTS}

The authors appreciate the Department of Research Golestan University of Medical Sciences for their financial support.

GOLALIPOUR, M. J.; GHAFARI, S.; LATIFIMOGHADAM, M. H. \& KABOLI, S. Alteración de los astrocitos del giro dentado en ratas diabéticas: rol protector de Urtica dioica. Int. J. Morphol., 29(4):1307-1312, 2011.

RESUMEN: La diabetes mellitus puede provocar alteraciones de los astrocitos en el sistema nervioso central. La Urtica dioica (ortiga) es una de varias especies incluidas para su uso contra la diabetes en la medicina popular. Este estudio se realizó para evaluar el efecto protector de la Urtica dioica sobre la densidad de 
los astrocitos en el giro dentado en ratas con diabetes inducida por STZ. En este estudio experimental 21 ratas albinas Wistar fueron asignadas al azar equitativamente en grupos normal, diabético y protegido (diabéticos tratados con ortiga). La hiperglicemia fue inducida por estreptozotocina $(80 \mathrm{mg} / \mathrm{kg})$ en los grupos de animales diabéticos y en tratamiento protector. Previo a la inducción diabética, los animales del grupo protegido recibieron, por vía intraperitoneal, extracto hidroalcohólico de Urtica dioica $(100 \mathrm{mg} /$ $\mathrm{kg} /$ peso corporal/día) durante cinco días . Cuatro semanas después de la inducción de la diabetes, los animales fueron sacrificados y se tomaron secciones coronales de la formación del hipocampo dorsal de los hemisferios cerebrales derechos y se tiñeron con tinción PTAH. La densidad de área de los astrocitos fue medida y comparada en los tres grupos ( $\mathrm{p}<0,05)$. El número de astrocitos en

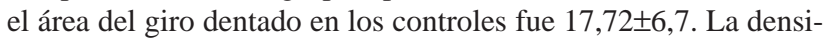
dad de los astrocitos aumentó con la diabetes $(24,26 \pm 9,5)$ en comparación con los controles. La densidad en las ratas tratadas con ortiga $(23,17 \pm 5,8)$ fue menor que las ratas diabéticas. Este estudio demostró que la administración del extracto de $U$. dioica antes de la inducción diabética no ayuda significativamente a la compensación de los astrocitos en el giro dentados de las ratas tratadas.

PALABRAS CLAVE: Diabetes; Astrocitos; Urtica dioica; Giro dentado.

\section{REFERENCES}

Afsari, Z. H.; Renno, W. M. \& Abd-El-Basset, E. Alteration of glial fibrillary acidic proteins immunoreactivity in astrocytes of the spinal cord diabetic rats. Anat. Rec., 291(4):390-9, 2008.

Atta-Ur-Rahman \& Zaman, K. Medicinal plants with hypoglycemic activity. J. Ethnopharmacol., 26(1):1-55, 1989.

Baydas, G.; Nedzvetskii, V. S.; Tuzcu, M.; Yasar, A. \& Kirichenko, S. V. Increase of glial fibrillary acidic protein and S-100B in hippocampus and cortex of diabetic rats: effects of vitamin $\mathrm{E}$. Eur. J. Pharmacol., 462(1-3):67-71, 2003 a.

Baydas, G.; Reiter, R. J.; Yasar, A.; Tuzcu, M.; Akdemir, I. \& Nedzvetskii, V. S. Melatonin reduces glial reactivity in the hippocampus, cortex, and cerebellum of streptozotocin-induced diabetic rats. Free Radic. Biol. Med., 35(7):797-804, 2003b.

Biessels, G. J. \& Gispen, W. H. The impact of diabetes on cognition: what can be learned from rodent models? Neurobiol. Aging, 26(1):36-41, 2005.

Biessels, G. J.; Kamal, A.; Ramakers, G. M.; Urban, I. J.; Spruijt, B. M.; Erkelens, D. W. \& Gispen,W. H. Place learning and hippocampal synaptic plasticity in streptozotocin induced diabetic rats. Diabetes, 45(9):1259-66, 1996.

Biessels, G. J.; Kappelle, A. C.; Bravenboer, B.; Erkelens, D. W. \& Gispen, W. H. Cerebral function in diabetes mellitus. Diabetologia, 37(7):643-50, 1994.
Brands, A. M.; Biessels, G. J.; de Haan, E. H.; Kappelle, L. J. \& Kessels, R. P. The effects of type 1 diabetes on cognitive performance: a meta-analysis. Diabetes Care, 28(3):726-35, 2005.

Dringen, R.; Gutterer, J. M. \& Hirrlinger, J. Glutathione metabolism in brain metabolic interaction between astrocytes and neurons in the defense against reactive oxygen species. Eur. J. Biochem., 267(16):4912-6, 2000.

Farzami, B.; Ahmadvand, D.; Vardasbi, S.; Majin, F. J. \& Khaghani, Sh. Induction of insulin secretion by a component of Urtica dioica leave extract in perifused Islets of Langerhans and its in vivo effects in normal and streptozotocin diabetic rats. $J$. Ethnopharmacol., 89(1):47-53, 2003.

Fazeli, S. A.; Gharravi, A. M.; Ghafari, S.; Jahanshahi, M. \& Golalipour, M. J. The granule cell density of the dentate gyrus following administration of Urtica dioica extract to young diabetic rats. Folia Morphol, 67(3):196-204, 2008.

Fazeli, S. A.; Gharravi, A. M.; Ghafari, S.; Jahanshahi, M. \& Golalipour, M. J. Effects of Urtica dioica extract on CA3 hippocampal pyramidal cell loss in young diabetic rats. Neural Regeneration Res., 5(12):901-5, 2010.

Gispen, W. H. \& Biessels, G. J. Cognition and synaptic plasticity in diabetes mellitus. Trends Neurosci., 23(11):542-9, 2000.

Gülçin, I.; Küfrevioglu, O. I.; Oktay, M. \& Büyükokuroglu, M. E. Antioxidant, antimicrobial, antiulcer and analgesic activities of nettle (Urtica dioica L.). J. Ethnopharmacol., 90(2-3):20515, 2004.

Jahanshahi, M.; Golalipour, M. J. \& Afshar, M. The effect of Urtica dioica extract on the number of astrocytes in the dentate gyrus of diabetic rats. Folia Morphol., 68(2):93-7, 2009.

Kameswara Rao, B.; Renuka Sudarshan, P.; Rajasekhar, M. D.; Nagaraju, N. \& Appa Rao, Ch. Antidiabetic activity of Terminalia pallida fruit in alloxan induced diabetic rats. $J$. Ethnopharmacol., 85(1):169-72, 2003.

Kavalali, G.; Tuncel, H.; Göksel, S. \& Hatemi, H. H. Hypoglycemic activity of Urtica pilulifera in streptozotocin-diabetic rats. $J$. Ethnopharmacol., 84(2-3):241-5, 2003.

Ladeji, O.; Omekarah, I. \& Solomon, M. Hypoglycemic properties of aqueous bark extract of Ceiba pentandra in streptozotocininduced diabetic rats. J. Ethnopharmacol., 84(2-3):139-42, 2003.

Liang, X. C.; Guo, S. S. \& Hagino, N. Current status of clinical and experimental researches on cognitive impairment in diabetes. Chin. J. Integr. Med., 12(1):68-74, 2006.

Morgan, T. E.; Rozovsky, I.; Goldsmith, S. K.; Stone, D. J.; Yoshida, T. \& Finch, C. E. Increased transcription of the astrocyte gene GFAP during middle-age is attenuated by food restriction: 
GOLALIPOUR, M. J.; GHAFARI, S.; LATIFIMOGHADAM, M. H. \& KABOLI, S. Alteration of dentate gyrus astrocytes in diabetic rats: Protective role of Urtica dioica. Int. J. Morphol., 29(4):1307-1312, 2011.

implications for the role of oxidative stress. Free Radic. Biol. Med., 23(3):524-8, 1997.

Muranyi, M.; Ding, C.; He, Q.; Lin, Y. \& Li, P. A. Streptozotocininduced diabetes causes astrocyte death after ischemia and reperfusion injury. Diabetes, 55(2):349-55, 2006.

Revsin, Y.; Saravia, F.; Roig, P.; Lima, A.; de Kloet, E. R.; HomoDelarche, F. \& De Nicola, A. F. Neuronal and astroglial alterations in the hippocampus of a mouse model for type 1 diabetes. Brain Res., 1038(1):22-31, 2005.

Saravia, F. E.; Revsin, Y.; Gonzalez Deniselle, M. C.; Gonzalez, S. L.; Roig, P.; Lima, A.; Homo-Delarche, F. \& De Nicola, A. F. Increased astrocyte reactivity in the hippocampus of murine models of type 1 diabetes: the nonobese diabetic (NOD) and streptozotocin-treated mice. Brain Res., 957(2):345-53, 2002.

Trudeau, F.; Gagnon, S. \& Massicotte, G. Hippocampal synaptic plasticity and glutamate receptor regulation: influences of diabetes mellitus. Eur. J. Pharmacol., 490(1-3):177-86, 2004.

Tsacopoulos, M. \& Magistretti, P. J. Metabolic coupling between glia and neurons. J. Neurosci., 16(3):877-85, 1996.

Vats, V.; Grover, J. K. \& Rathi, S. S. Evaluation of antihyperglycemic and hypoglycemic effect of Trigonella foenumgraecum Linn, Ocimum sanctum Linn and Pterocarpus marsupium Linn in normal and alloxanized diabetic rats. $J$. Ethnopharmacol., 79(1):95-100, 2002.

Zonta, M.; Angulo, M. C.; Gobbo, S.; Rosengarten, B.; Hossmann, K. A.; Pozzan, T. \& Carmignoto, G. Neuron-to-astrocyte signaling is central to the dynamic control of brain microcirculation. Nat. Neurosci., 6(1):43-50, 2003.
Correspondence to:

Dr. Mohammad Jafar Golalipour

Gorgan Congenital Malformations Research Center, Department of Anatomical Sciences

Golestan University of Medical Sciences

Gorgan

P.O. Box: $49175-1141$

IRAN

Phone: + 98(171)4425165,

Fax $+98(171) 4425660$

Email: mjgolalipour@yahoo.com

Received: 28-05-2011

Accepted: 04-08-2011 